\title{
molecules
}

ISSN 1420-3049

(C) 2008 by MDPI

www.mdpi.org/molecules

Full Paper

\section{Effects of Anonaine on Dopamine Biosynthesis and L-DOPA-Induced Cytotoxicity in PC12 Cells}

\author{
Jae Joon Lee ${ }^{1}$, Chun Mei Jin ${ }^{1}$, Young Kyoon Kim ${ }^{2}$, Shi Yong Ryu ${ }^{3}$, Sung Cil Lim ${ }^{1}$ and \\ Myung Koo Lee ${ }^{1, *}$
}

${ }^{1}$ College of Pharmacy and Research Center for Bioresource and Health, Chungbuk National University, 12, Gaeshin-dong, Heungduk-gu, Cheongju 361-763, Korea; E-mail: jaejlee@hanmail.net (Jae Joon Lee); jinchm73@daum.net (Chun Mei Jin); slim@chungbuk.ac.kr (Sung Cil Lim)

${ }^{2}$ College of Forest Science, Kookmin University, Seoul 136-702, Korea; E-mail: ykkim@kookmin.ac.kr (Young Kyoon Kim)

${ }^{3}$ Korea Research Institute of Chemical Technology, Taejeon 305-606, Korea; E-mail: syryu@krict.re.kr (Shi Yong Ryu)

* Author to whom correspondence should be addressed. E-mail: myklee@chungbuk.ac.kr; Tel: +82-43-262-2822, Fax: +82-43-276-2754.

Received: 30 January 2008; in revised form: 22 February 2008 / Accepted: 25 February 2008 / Published: 27 February 2008

\begin{abstract}
The effects of anonaine, an aporphine isoquinoline alkaloid, on dopamine biosynthesis and L-DOPA-induced cytotoxicity in PC12 cells were investigated. Anonaine at concentration ranges of $0.01-0.2 \mu \mathrm{M}$ showed a significant inhibition of dopamine content at $24 \mathrm{~h}$, with an $\mathrm{IC}_{50}$ value of $0.05 \mu \mathrm{M}$. Anonaine at $0.05 \mu \mathrm{M}$ inhibited tyrosine hydroxylase (TH) and aromatic L-amino acid decarboxylase (AADC) activities to 38.4$40.2 \%$ and $78.4-90.2 \%$ of control levels at 12-24 $\mathrm{h}$ and 3-6 h, respectively. TH activity was more influenced than AADC activity. Anonaine also decreased intracellular cyclic AMP levels, but not intracellular $\mathrm{Ca}^{2+}$ concentrations. In addition, anonaine $(0.05 \mu \mathrm{M})$ reduced L-DOPA (50 $\mu \mathrm{M}$ and $100 \mu \mathrm{M}$ )-induced increases in dopamine content at $24 \mathrm{~h}$. However, anonaine $(0.05 \mu \mathrm{M})$ did not enhance L-DOPA (50 $\mu \mathrm{M}$ and $100 \mu \mathrm{M})$-induced cell death
\end{abstract}


after $24 \mathrm{~h}$. These results suggest that anonaine inhibits dopamine biosynthesis by mainly reducing TH activity without aggravating L-DOPA-induced cytotoxicity in PC12 cells.

Keywords: Anonaine; Dopamine biosynthesis; L-DOPA-induced cytotoxicity; PC12 cells.

\section{Introduction}

Anonaine (A, Figure 1) is an aporphine isoquinoline alkaloid isolated from the plant species Magnolia ovobata Thun. (Magnoliaceae). Anonaine shows antiperoxidative [1], antibacterial and antifungal activities [2]. Anonaine also displays intense dopamine-uptake inhibitory properties, which can lead to a potential anti-depressant activity [3].

Figure 1. Chemical structures of anonaine (A) and liriodenine (B).

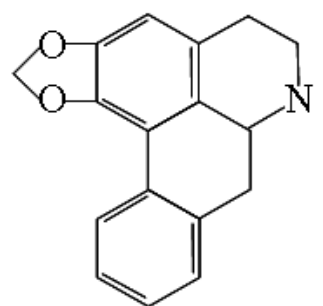

(A)<smiles>O=C1c2ccccc2-c2c3c(cc4ccnc1c24)OCO3</smiles>

(B)

In dopamine biosynthetic pathways, tyrosine hydroxylase (TH, EC 1.14.16.2), which is the first and rate-limiting enzyme, catalyzes the conversion of L-tyrosine to L-3,4-dihydroxyphenylalanine (LDOPA) and L-DOPA is then converted to dopamine by aromatic L-amino acid decarboxylase (AADC, EC 4.1.1.28). Intracellular cyclic AMP level and $\mathrm{Ca}^{2+}$ concentration are known to regulate $\mathrm{TH}$ activity and $\mathrm{TH}$ gene expression via protein kinase $\mathrm{A}$ (PKA), protein kinase $\mathrm{C}(\mathrm{PKC})$ and $\mathrm{Ca}^{2+} / \mathrm{calmodulin}$ kinase II in PC12 cells [4,5]. AADC is also modulated in the central nervous system as is TH [6]. LDOPA is the most frequently prescribed drug for controlling the symptoms of Parkinson's disease [7], but it has been found to accelerate deterioration of Parkinson patients' condition after long-term treatment [8] and can induce cytotoxicity in neuronal and PC12 cells [8,9].

Aporphine alkaloids such as bulbocapnine and liriodenine (B, Figure 1) showed inhibitory effects on dopamine biosynthesis in PC12 cells [10,11]. In addition, boldine, glaucine and some halogenated boldine derivatives, which are also based on the aporphine skeleton, appear to exhibit anti-oxidant properties [12] and brain anti-dopaminergic activities [13,14]. However, the dopamine-related pharmacological functions on anonaine are poorly understood. PC12 rat adrenal pheochromocytoma cell lines have dopamine synthesizing, storing and releasing properties, similar to those of neurons [15]. PC12 cells also express the catecholamine biosynthetic enzymes such as TH, AADC and dopamine $\beta$ - 
hydroxylase (EC 4.14.17.1) [15,16]. In the present study, therefore, the inhibitory effects of anonaine on dopamine biosynthesis and L-DOPA-induced cytotoxicity in PC12 cells were examined.

\section{Results and Discussion}

Intracellular dopamine content

Anonaine at concentration ranges of 0.01-0.2 $\mu \mathrm{M}$ reduced the intracellular dopamine content of PC12 cells in a concentration-dependent manner after $24 \mathrm{~h}$ exposure $(57.8 \%$ inhibition at $0.06 \mu \mathrm{M})$. The $\mathrm{IC}_{50}$ value of anonaine was $0.05 \mu \mathrm{M}$ (Table 1). Anonaine at concentrations up to $0.5 \mu \mathrm{M}$ were not cytotoxic and did not change the cell morphology for $48 \mathrm{~h}$ towards PC12 cells. However, at concentrations higher than $1 \mu \mathrm{M}$, anonaine caused a severe cytotoxicity for $48 \mathrm{~h}$, as determined by MTT assay. Therefore, $0.05 \mu \mathrm{M}$ anonaine was used in subsequent experiments.

Table 1. Inhibitory effects of anonaine on dopamine content in PC12 cells. PC12 cells were treated with anonaine for $24 \mathrm{~h}$. The cells were harvested with phosphate buffered saline and dopamine content was measured by an HPLC method. The control value of dopamine content was $3.70 \pm 0.23 \mathrm{nmol} / \mathrm{mg}$ protein. Results represent means \pm S.E.M of $6-8$ dishes. ${ }^{*} \mathrm{P}<0.05$, ${ }^{* *} \mathrm{P}<0.01,{ }^{* * *} \mathrm{P}<0.001$ compared to control levels (ANOVA followed by Tukey’s test).

\begin{tabular}{lcll}
\hline & $\begin{array}{c}\text { Dopamine content } \\
\text { (nmol/mg protein) }\end{array}$ & (\% of control) & IC $_{50}$ value \\
\hline Control & $3.70 \pm 0.23$ & $(100)$ & \\
Anonaine & & & $0.05 \mu \mathrm{M}$ \\
$0.01 \mu \mathrm{M}$ & $3.05 \pm 0.26$ & $(82.4)$ & \\
$0.03 \mu \mathrm{M}$ & $2.55 \pm 0.17$ & $(68.9)^{*}$ \\
$0.06 \mu \mathrm{M}$ & $1.56 \pm 0.19$ & $(42.2)^{* *}$ & \\
$0.08 \mu \mathrm{M}$ & $0.94 \pm 0.15$ & $(25.4)^{* * *}$ & \\
\hline
\end{tabular}

Dopamine content began to decrease at $1 \mathrm{~h}$ and reached minimal levels (about $37.7 \%$ of control levels) at $12 \mathrm{~h}$ after exposure to $0.05 \mu \mathrm{M}$ anonaine (Figure 2A). The decreased dopamine levels started to recover at $24 \mathrm{~h}$ and then reached the control levels at $72 \mathrm{~h}$. The dopamine content in the medium, which was secreted from intracellular dopamine stores in PC12 cells, was increased to $472 \%$ compared to control levels at $30 \mathrm{~min}$ by treatment of $0.05 \mu \mathrm{M}$ anonaine (Figure 2B). However, the extracellular dopamine content did not increase after $3 \mathrm{~h}$. 
Figure 2. Time courses of intracellular (A) and extracellular (B) dopamine content by anonaine $(0.05 \mu \mathrm{M})$ in PC12 cells. The intracellular and extracellular dopamine content of control levels were $3.78 \pm 0.26$ and $0.15 \pm 0.05 \mathrm{nmol} / \mathrm{mg}$ protein, respectively. Results represent means \pm S.E.M. of 6-8 dishes. Significantly different from control values: $* * * \mathrm{P}<0.001$ (ANOVA followed by Tukey’s test).

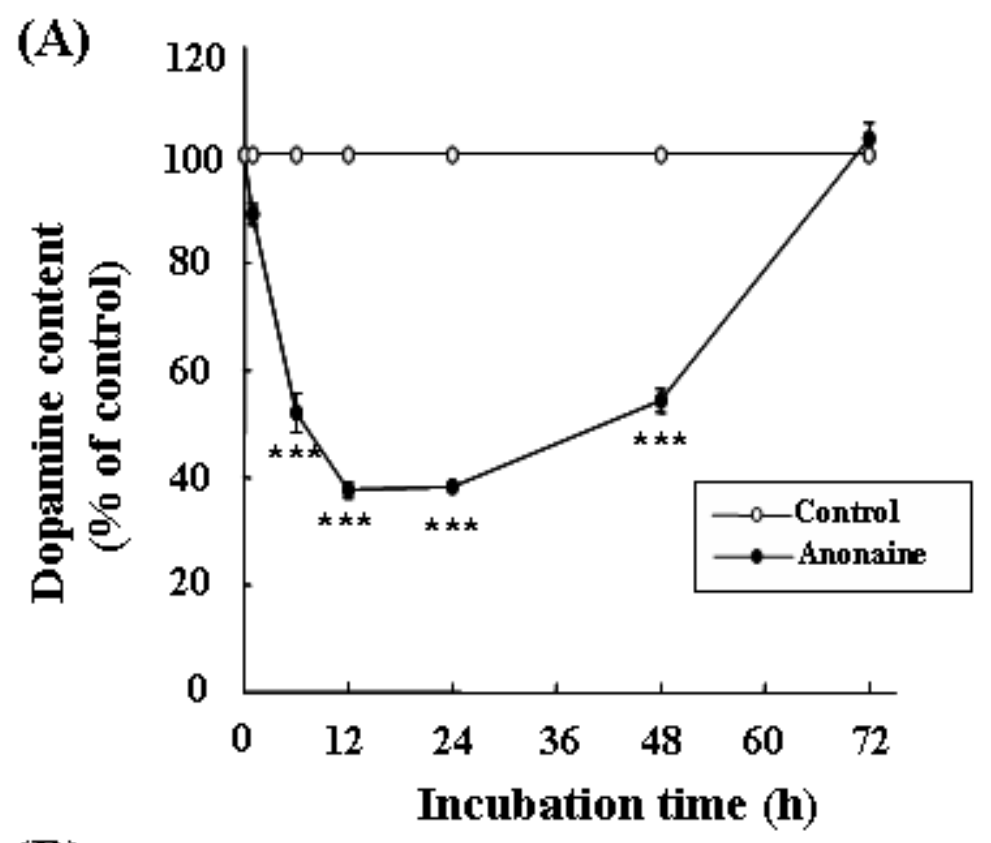

(B)

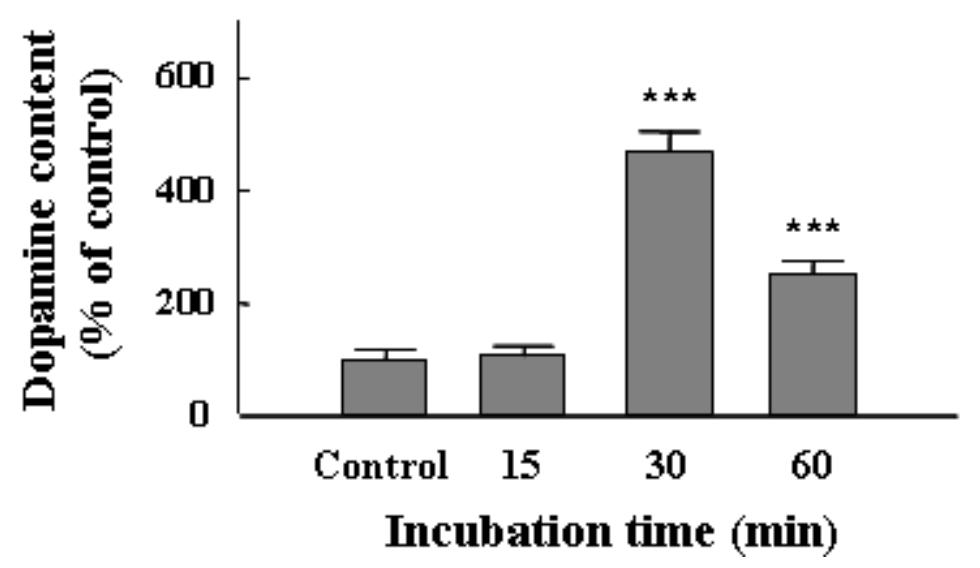

TH and $A A D C$ activities

TH activity was inhibited by $0.05 \mu \mathrm{M}$ anonaine to $38.4-61.2 \%$ of control levels at $12-48 \mathrm{~h}$ and recovered to $88.5 \%$ of control at $72 \mathrm{~h}$ (Figure 3A). AADC activity was also inhibited to $78.4 \%$ of control levels at $3 \mathrm{~h}$ and then recovered rapidly to control levels at about 6-12 h with $0.05 \mu \mathrm{M}$ anonaine (Figure 3B). TH activity was more markedly inhibited by anonaine for a longer period than AADC activity. 
Figure 3. Time courses of TH (A) and AADC (B) activities by anonaine $(0.05 \mu \mathrm{M})$ in PC12 cells. The control values of the activities of TH and AADC were $3.68 \pm 0.29$ and $32.5 \pm 3.51 \mathrm{nmol} / \mathrm{min} / \mathrm{mg}$ protein. Results represent means \pm S.E.M. of 6-8 dishes. Significantly different from control values: $* \mathrm{P}<0.05, * * \mathrm{P}<0.01, * * * \mathrm{P}<0.001$ (ANOVA followed by Tukey's test).
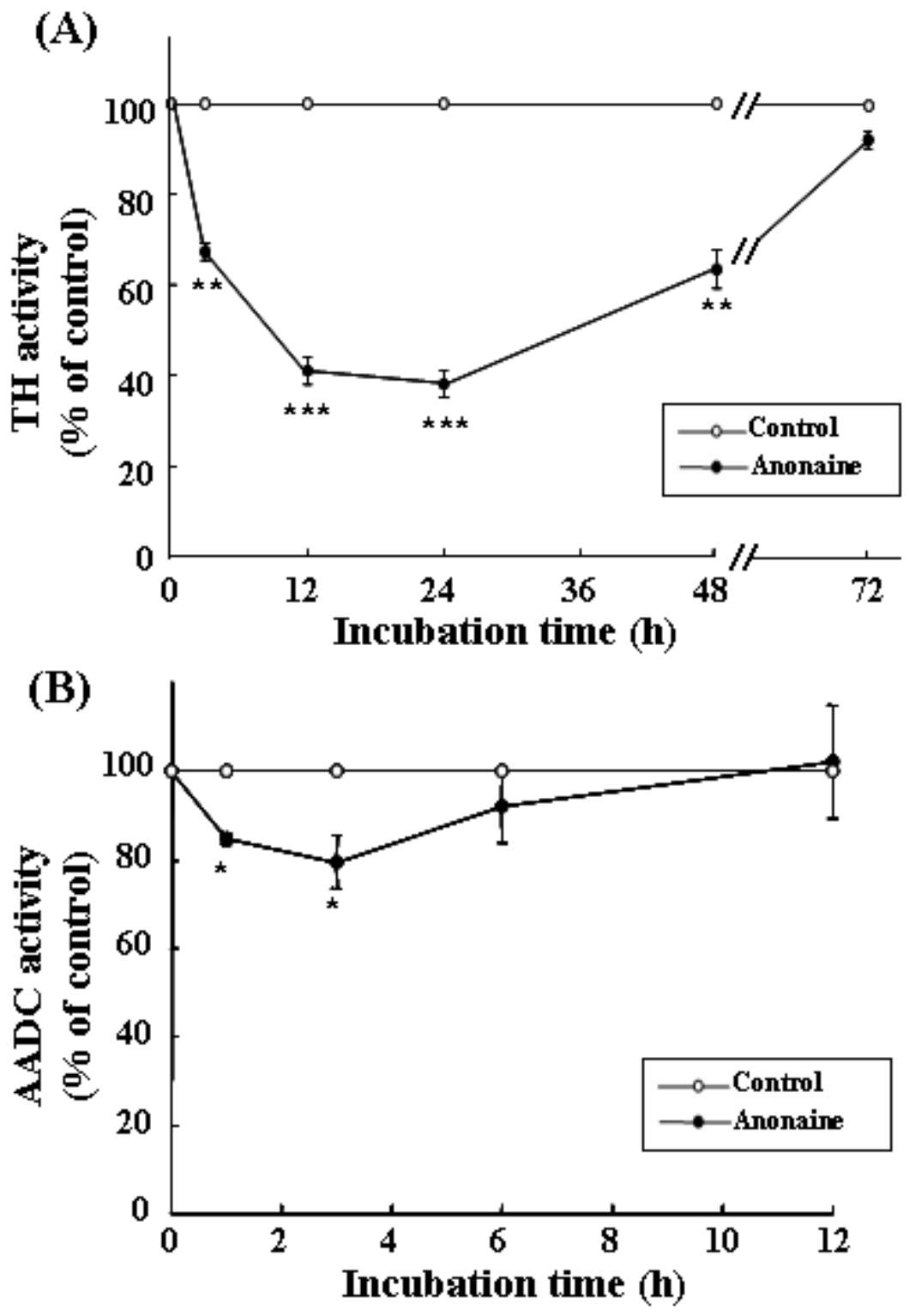

TH mRNA and cyclic AMP levels, and $\mathrm{Ca}^{2+}$ concentration

TH mRNA levels were slightly decreased at about 6-24 h after exposure to $0.05 \mu \mathrm{M}$ anonaine: the decreased intensity was weak (Figure 4). In addition, anonaine at $0.05 \mu \mathrm{M}$ significantly decreased intracellular cyclic AMP levels to 40.1-41.3\% of control levels at 10 and 60 min (Figure 5A). However, intracellular $\mathrm{Ca}^{2+}$ concentration was not reduced by $0.05 \mu \mathrm{M}$ anonaine (Figure $5 \mathrm{~B}$ ). 
Figure 4. Effects of anonaine on TH mRNA levels in PC12 cells. RNA was extracted and $10 \mu \mathrm{g}$ aliquots were subjected to electrophoresis on formaldehyde gels, blotted onto nylon membrane and probed with ${ }^{32}$ P-labeled cDNA probes for rat $\mathrm{TH}$ and $\alpha$-tubulin. Equal loading of the gels was verified by ethidium bromide staining of total RNA. Relative densitometry ratio in control was expressed as 1 arbitrary unit (means \pm S.E.M., $\mathrm{n}=3$ ). Significantly different from control values: $* \mathrm{P}<0.05$ (ANOVA followed by Tukey’s test).

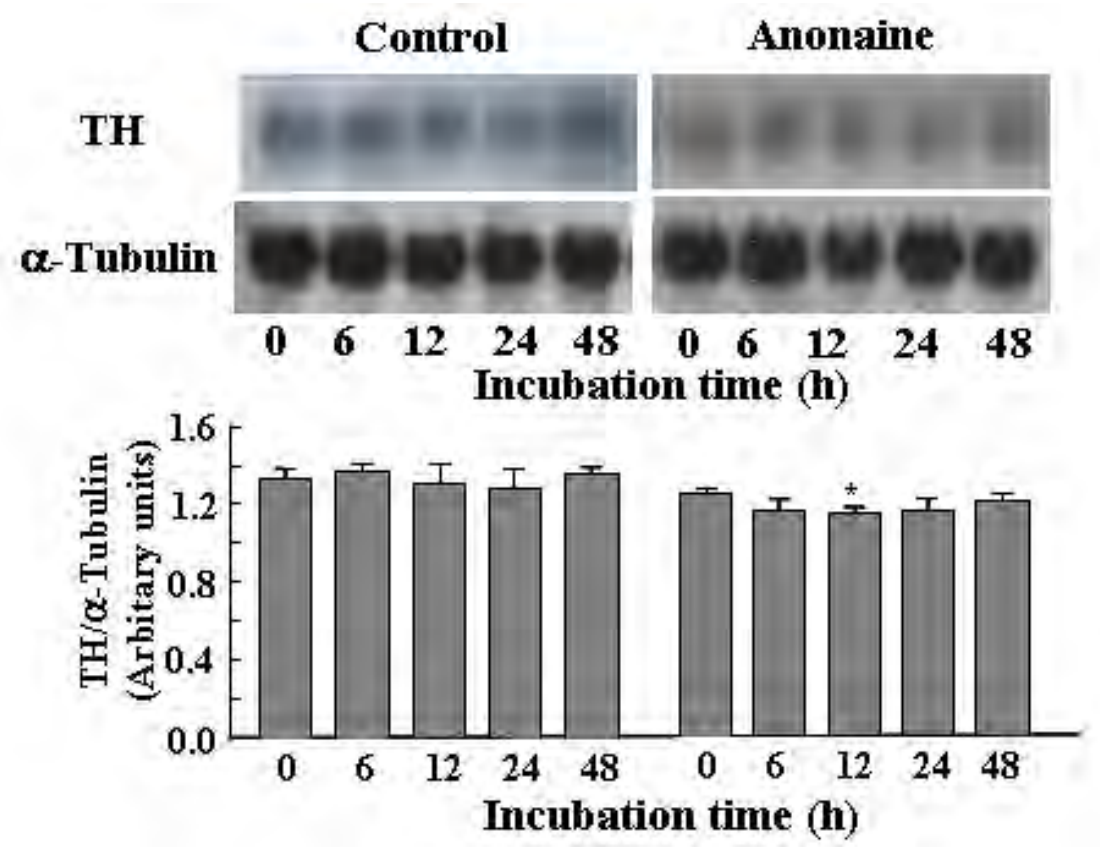

L-DOPA-induced dopamine biosynthesis and cytotoxicity

L-DOPA at $50 \mu \mathrm{M}$ and $100 \mu \mathrm{M}$ for $24 \mathrm{~h}$ increased intracellular dopamine content to $253 \%$ and $280 \%$, respectively, compared to untreated control in PC12 cells (Figure 6A) [17]. When 50-100 $\mu \mathrm{M}$ L-DOPA was associated with $0.05 \mu \mathrm{M}$ anonaine, the intracellular dopamine content was significantly decreased by $98.2 \%$ and 105\%, compared to L-DOPA alone (Figure 6A). Similar patterns were also observed after $48 \mathrm{~h}$ of incubation (data not shown). In addition, $50 \mu \mathrm{M}$ and $100 \mu \mathrm{M}$ L-DOPA for $24 \mathrm{~h}$ reduced cell viability to $90.8 \%$ and $79.5 \%$ of control levels (Figure 6B) [17]. However, when $50 \mu \mathrm{M}$ and $100 \mu \mathrm{M}$ L-DOPA were associated with $0.05 \mu \mathrm{M}$ anonaine for $24 \mathrm{~h}$, the cell viability showed moderate increases of $6.1 \%$ and $6.0 \%$, compared to L-DOPA alone (Figure 6B). Co-treatments with 20 $\mu \mathrm{M}$ and $50 \mu \mathrm{M}$ L-DOPA plus $0.05 \mu \mathrm{M}$ anonaine for 48 h resulted in about $10.0 \%$ and $7.7 \%$ increases of cell viability from $83.1 \%$ and $71.2 \%$, respectively, compared to the corresponding concentrations of L-DOPA alone (data not shown).

Isoquinoline alkaloids such as higenamine, berberine, palmatine, ethaverine, hydrastine and tetrahydropapaveroline were found to regulate dopamine biosynthesis by reducing TH activity in PC12 cells [18-22]. Aporphine alkaloids such as bulbocapnine and liriodenine also reduced dopamine content in PC12 cells [10,11]. In addition, tetrahydropapaveroline, berberine, palmatine, hydrastine and bulbocapnine inhibited TH activity, which was prepared from bovine adrenal gland [22-25]. 
Dopamine biosynthesis was regulated by TH and AADC activities [6,26], which were activated by cyclic AMP and $\mathrm{Ca}^{2+}$ concentrations mediated by PKA, PKC and $\mathrm{Ca}^{2+} /$ calmodulin kinase [4,5]. In this study, anonaine at $0.05 \mu \mathrm{M}$ decreased intracellular dopamine content and L-DOPA-induced increases in dopamine content in PC12 cells (Figures 2A, 6A). Both TH and AADC activities were inhibited by $0.05 \mu \mathrm{M}$ anonaine: the inhibition of TH activity was stronger and longer than that of AADC activity (Figure 3). Anonaine also showed inhibitory trends of TH mRNA levels, but not significant (Figure 4). Anonaine decreased cyclic AMP levels at 10-60 min (Figure 5A), but not reduced basal $\mathrm{Ca}^{2+}$ concentration (Figure 5B).

Figure 5. Effects of anonaine on cyclic AMP level (A) and $\mathrm{Ca}^{2+}$ concentration (B) in PC12 cells. PC12 cells were treated with anonaine $(0.05 \mu \mathrm{M})$ and incubated at $37^{\circ} \mathrm{C}$ for 10 min. Intracellular cyclic AMP levels were measured by enzyme immunoassay kit. PC12 cells were also loaded with fura-2 AM for 10-60 min, and intracellular $\mathrm{Ca}^{2+}$ concentration was assayed described under Materials and methods. Cyclic AMP levels of control were $241.6 \pm 12.5 \mathrm{pmol} / \mathrm{mg}$ protein. Results represent means \pm S.E.M. of 6-8 wells. Significantly different from control values: ${ }^{* * *} \mathrm{P}<0.001$ (ANOVA followed by Tukey's test).

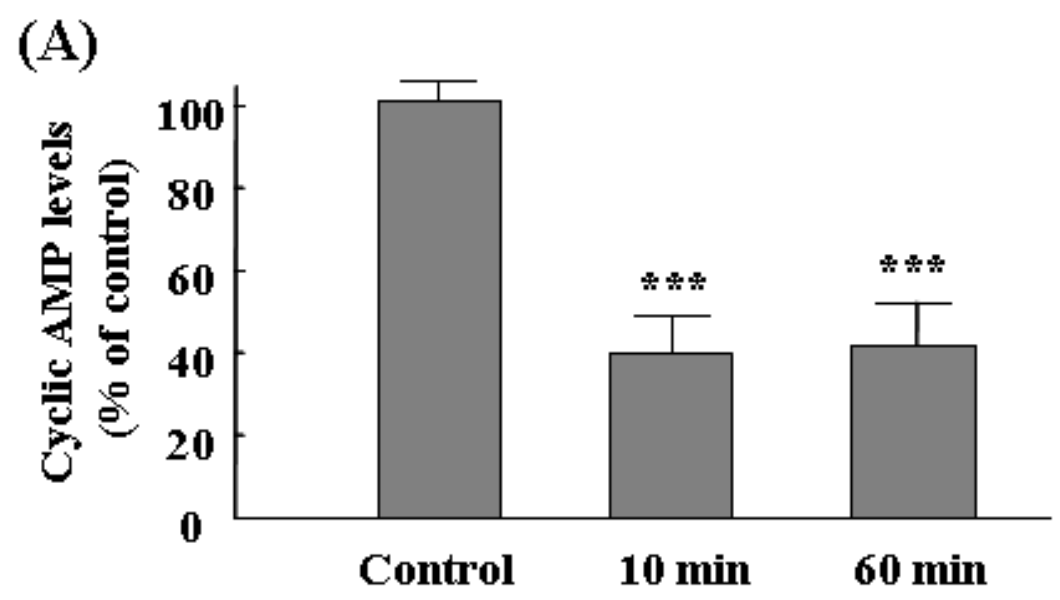

(B)

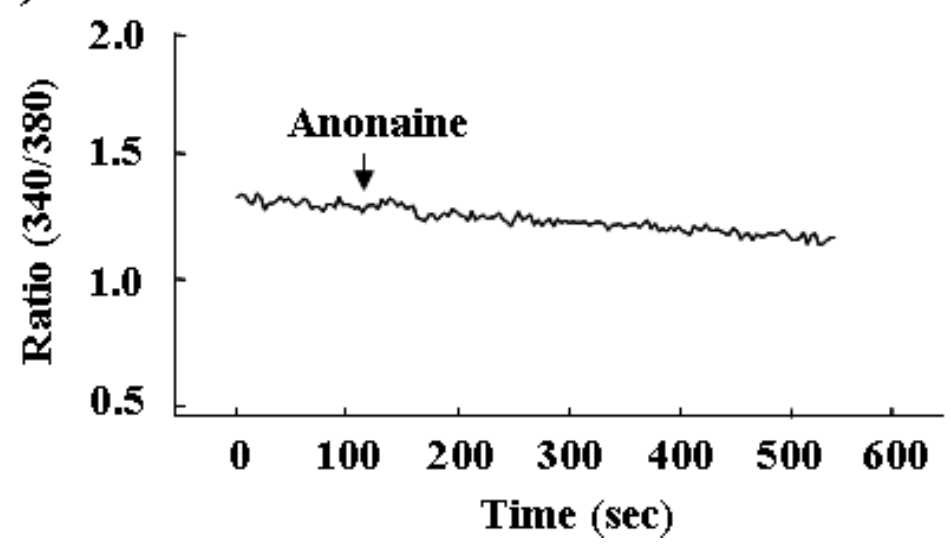


Figure 6. Effects of anonaine on L-DOPA-induced dopamine content (A) and cytotoxicity (B) in PC12 cells. PC12 cells were exposed to L-DOPA (50 $\mu \mathrm{M}$ and $100 \mu \mathrm{M})$ in the absence or presence of anonaine $(0.05 \mu \mathrm{M})$ for $24 \mathrm{~h}$. Dopamine content and cell viability were determined by an HPLC system and MTT method as described under Materials and Methods. Results represent means \pm S.E.M. of 6-8 dishes or wells. ${ }^{*} \mathrm{P}<0.05$ compared to control values, $\# \mathrm{P}<0.05$ compared to the corresponding $L$-DOPA concentrations (ANOVA followed by Tukey's test).
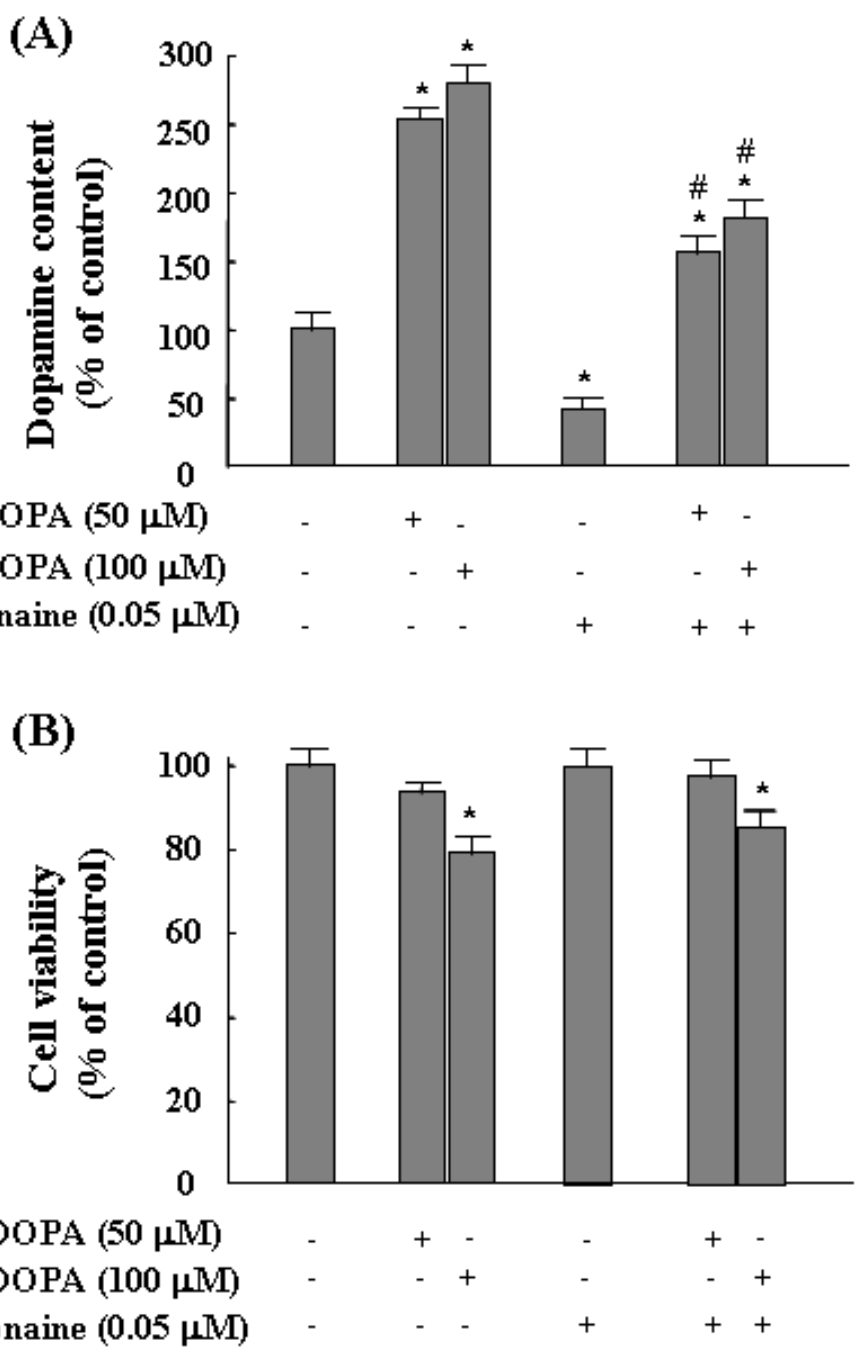

The total decreased dopamine content by long term-treated anonaine (24-48 h) could not be affected by extracellular dopamine release at early time points (0.5-1 h) (Figures 2A, 2B). These results suggest that anonaine can inhibit dopamine biosynthesis by mainly reducing $\mathrm{TH}$ activity in PC12 cells. It has been found that the cytotoxic action of L-DOPA is mediated by reactive oxygen species such as hydrogen peroxide, associated with oxygen free radicals and quinone derivatives [9]. In our previously studies, 20-100 $\mu \mathrm{M}$ L-DOPA increases dopamine content after $24 \mathrm{~h}$ in PC12 cells $[17,21]$. However, at concentrations higher than $50 \mu \mathrm{M}$ for $48 \mathrm{~h}$ L-DOPA induces intracellular cytotoxicity by oxidative stress [17,27]. Tetrahydropapaveroline and hydrastine also aggravate LDOPA (50-100 $\mu \mathrm{M})$-induced cytotoxicity in PC12 cells [17,27]. In contrast, phenolic aporphine alkaloids such as bulbocapnine and boldine exhibit anti-peroxidative and anti-oxidant effects [28,29]. 
Boldine also decreases dopamine-induced death in PC12 cells [29]. In addition, glaucine, the nonphenolic dimethyl ether of boldine, showed a potent anti-oxidant activity [14]. In the present study, when L-DOPA (50-100 $\mu \mathrm{M})$ was associated with anonaine $(0.05 \mu \mathrm{M})$, the cell viability was slightly increased compared with L-DOPA alone (Figure 6B). However, anonaine could not show a significant protective activity against L-DOPA (50-100 $\mu \mathrm{M})$-induced cytotoxicity at 24-48 h in PC12 cells.

The order of inhibitory potency on dopamine biosynthesis was: anonaine > liriodenine > bulbocapnine, in comparison with their $\mathrm{IC}_{50}$ values (anonaine, $0.05 \mu \mathrm{M}$; liriodenine, $8.4 \mu \mathrm{M}$; bulbocapnine $26.7 \mu \mathrm{M}$ ) [10,11]. Therefore, it is suggested that the isoquinoline ring planarity (liriodenine and anonaine) (Figure 1) and the 11-hydroxy and methoxy groups of the aporphine alkaloid structure (bulbocapnine) play a key role in the inhibition of dopamine biosynthesis in PC12 cells. Liriodenine, a very planar molecule (Figure 1, B), is a strong topoisomerase II inhibitor presenting DNA intercalation [30]. However, bulbocapnine, which does not possess a planar conformation, is inactive as a topoisomerase II inhibitor and does not unwind DNA [30]. Liriodenine reduced TH mRNA levels in PC12 cells [11], however, bulbocapnine did not affect them [10]. Therefore, it is proposed that a planar molecule anonaine might have a weak DNA-binding activity, which could not reduce TH mRNA levels significantly (Figure 4).

\section{Conclusions}

In summary, anonaine inhibited dopamine biosynthesis by mainly reducing TH activity in PC12 cells. Anonaine also reduced L-DOPA-induced increases in dopamine content without aggravating LDOPA-induced cell death. The in vivo pharmacological applications of anonaine need to be further studied.

\section{Experimental}

\section{Materials}

Anonaine was supplied by the Korea Research Institute of Chemical Technology [31]. 3-(4,5Dimethyl-2-thiazolyl)-2,5-di-phenyl-2H-tetrazolium bromide (MTT), L-DOPA, L-tyrosine, DL-6methyl-5,6,7,8-tetrahydropterine and Fura-2 AM were purchased from Sigma Chemical Co. (St. Louis, MO, USA). Cyclic AMP enzyme immunoassay kit was purchased from Amersham Pharmacia Biotech (Little Chalfont, Buckinghamshire, UK). All sera, antibiotics and RPMI 1640 for cell culture were obtained from Gibco (Grand Island, NY, USA). All other chemicals were of reagent grade.

\section{Cell culture}

PC12 cells were grown in RPMI medium 1640 supplemented with 10\% heat-inactivated horse serum, 5\% heat-inactivated fetal bovine serum, 100 units $/ \mathrm{mL}$ penicillin and $100 \mu \mathrm{L} / \mathrm{mL}$ streptomycin. The cells were placed in a humidified atmosphere with $5 \% \mathrm{CO}_{2}$ and $95 \%$ air at $37^{\circ} \mathrm{C}$ [15]. 


\section{Determination of dopamine content}

Intracellular and extracellular dopamine content was analyzed by HPLC [10,19]. Briefly, trichloroacetic acid (1 M, $100 \mu \mathrm{L}$ ) and isoproterenol (150 pmol, internal standard) were added to the pellet extracts. The mixture was passed through a Toyopak SP-M cartridge $\left(\mathrm{Na}^{+}\right.$, resin $1 \mathrm{~mL}$, Toso, Tokyo, Japan). The cartridge eluate was derivatized with 1,2-diphenylethylenediamine and the final reaction mixture was injected into an HPLC system (Toso). The HPLC conditions were identical to those described previously [19].

\section{Assay for TH and AADC activities}

TH activity was measured according to a slight modification of the procedure of Nagatsu et al. [32] as described previously [19]. The amount of L-DOPA produced from the substrate L-tyrosine was determined using an HPLC equipped with a CM8010 electrochemical detector (Toso) as described previously [19]. For the determination of AADC activity, the amount of dopamine formed from the substrate L-DOPA at $37^{\circ} \mathrm{C}$ for 10 min was also determined by HPLC [19,33].

\section{RNA extraction and Northern blotting}

Total RNA from PC12 cells was isolated and separated by electrophoresis on 1\% agarose gel containing 0.66 M formaldehyde and transferred to a nylon membrane (ICN, East Hills, NY, USA) [34]. The Northern blot analysis for TH mRNA was performed by hybridizing to the coding regions of the $0.7 \mathrm{~kb}$ rat TH cDNA probe labeled with $\left[\alpha_{-}{ }^{32} \mathrm{P}\right.$ ] dCTP [4] using a Random Primer labeling system (DuPont NEN, Boston, MA, USA). Rat $\alpha$-tubulin was used as an internal standard. After exposure of blots to X-ray film, the auto-radiographs were quantified by scanning laser densitometry (Ultra Scan XL, LKB, Bromma, Sweden).

\section{Measurement of cyclic AMP levels}

The cyclic AMP levels in PC12 cells were measured using an enzyme immunoassay system kit. PC12 cells were incubated in 96-well plate overnight at $37^{\circ} \mathrm{C}$. The cells were incubated for a suitable time and agitated after lysis reagent was added. Finally, the absorbance was determined using a Microplate Reader (Molecular Devices, CA, USA) at $450 \mathrm{~nm}$.

\section{Measurement of intracellular $\mathrm{Ca}^{2+}$ concentration}

PC12 cells were harvested and washed with modified Krebs-Ringer-HEPES solution (pH adjusted to 7.4 with $\mathrm{NaOH}$ ) [11]. The cells were loaded with $5 \mu \mathrm{M}$ Fura-2 AM at $37^{\circ} \mathrm{C}$ for $30-60$ min and the fluorescence intensity was measured with a Luminescence Spectrometer (PTI, Photon Technology International Inc., USA, excitation wavelengths $340 \mathrm{~nm}$ and $380 \mathrm{~nm}$, emission wavelength $510 \mathrm{~nm}$ ). 
Measurement of cell viability: MTT assay

The cell viability was performed by MTT assay [35]. After PC12 cells were treated with the aporphine alkaloids, MTT solution (final concentration, $1 \mathrm{mg} / \mathrm{mL}$ ) was added to each well and further incubated for $4 \mathrm{~h}$ at $37^{\circ} \mathrm{C}$. The absorbance was then measured at $570 \mathrm{~nm}$ with a Bauty Diagnostic Microplate Reader (Molecular Devices, CA). Cell viability was expressed as a percentage of control value.

\section{Statistical analysis}

All data were presented as means \pm S.E.M. of at least four experiments. Protein amounts were determined using bovine serum albumin as a standard [36]. Statistical analysis was performed by ANOVA followed by Tukey’s test.

\section{Acknowledgements}

This work was supported by the Korean Research Foundation Grant funded by the Korean Government (MOEHRD) (The Regional Research Universities Program/Chungbuk BIT ResearchOriented University Consortium) (2007) and the financial support by the program of Research Center for Bioresource and Health, MOPS and ITEP (2007).

\section{References}

1. Martinez, L.A.; Rios, J.L.; Paya, M.; Alcaraz, M.J. Inhibition of nonenzymic lipid peroxidation by benzylisoquinoline alkaloids. Free Rad. Biol. Med. 1992, 12, 287-292.

2. Paulo, M. de Q.; Barbosa-Fiho, J.M.; Lima, E.O.; Maia, R.F.; Barbosa, R. de C.; Kaplan, M.A. Antimicrobial activity of benzylisoquinoline alkaloids from annona salzmanii D.C. J. Ethnopharmacol. 1992, 36, 39-41.

3. Protais, P.; Arbaoui, J.; Bakkali, E.H.; Bermejo, A.; Cortes, D. Effects of various isoquinoline alkaloids on in vitro 3H-dopamine uptake by rat striatal synaptosomes. J. Nat. Prod. 1995, 58, 1475-1484.

4. Kim, K.S.; Park, D.H.; Wessel, T.C.; Song, B.; Wagner, J.A.; Joh, T.H. A dual role for the cAMPdependent protein kinase in tyrosine hydroxylase gene expression. Proc. Natl. Acad. Sci. USA 1993, 90, 3471-3475.

5. Dunkley, P.R.; Cote, A.; Harrison, S.M.; Herd, L.; Hall, A.; Powis, D.A. Tyrosine hydroxylase phosphorylation in bovine adrenal chromaffin cells. Biochem. Pharmacol. 1996, 51, 239-245.

6. Young, E.A.; Duchemin A.-M.; Neff, N.H.; Hadjiconstantinou, M. Parallel modulation of striatal dopamine synthetic enzymes by second messenger pathways. Eur. J. Pharmacol. 1998, 357, 1523.

7. $\quad$ Marsden, C.D. Parkinson’s disease. J. Neurol. Neurosurg. Ps. 1994, 57, 672-681. 
8. Ziv, I.; Zilkha-Falb, R.; Offen, D.; Shirvan, A.; Barzilai, A.; Melamed, E. Levodopa induces apoptosis in cultured neuronal cells: a possible accelerator of nigrostriatal degeneration in Parkinson's disease? Mov. Disord. 1997, 12, 17-23.

9. Basma, A.N.; Morris, E.J.; Nicklas, W.J.; Geller, H.M. L-DOPA cytotoxicity to PC12 cells in culture is via its antoxidation. J. Neurochem. 1995, 64, 825-832.

10. Shin, J.S.; Kim, K.T.; Lee, M.K. Inhibitory effects of bulbocapnine on dopamine biosynthesis in PC12 cells. Neurosci. Lett. 1998, 244, 161-164.

11. Jin, C.H.; Lee, J.J.; Yang, Y.J.; Kim, Y.M.; Kim, Y.K.; Ryu, S.Y.; Lee, M.K. Liriodenine inhibits dopamine biosynthesis and L-DOPA-induced dopamine content in PC12 cells. Arch. Pharm. Res. 2007, 30, 984-990.

12. Cassels, B.K.; Asencio, M.; Conget, P.; Speisky, H.; Videla, L.A.; Lissi, E.A. Structureantioxidative activity relationships in benzylisoquinoline alkaloids. Pharmacol. Res. 1995, 31, 103-107.

13. Asencio, M.; Delaquerriere, B.; Cassels, B.K.; Speisky, H.; Comoy, E.; Protais, P. Biochemical and behavioral effects of boldine and glaucine on dopamine systems. Pharmacol. Biochem. Behav. 1999, 62, 7-13.

14. Loghin, F.; Chagraoui, A.; Asencio, M.; Comoy, E.; Speisky, H.; Cassels, B.; Protais, P. Effects of some antioxidative aporphine derivatives on striatal dopaminergic transmission and on MPTPinduced striatal dopamine depletion in B6CBA mice. Pharmacol. Sci. 2003, 18, 133-140.

15. Tischler, A.S.; Perlman, R.L.; Morse, G.M.; Sheard, B.E. Glucocorticoids increase catecholamine synthesis and storage in PC12 cells pheochromocytoma cell culture. J. Neurochem. 1983, 40, 364-370.

16. Byrd, J.C.; Hadjiconstantinou, M.; Cavalla, D. Epinephrine synthesis in the PC12 pheochromocytoma cell line. Eur. J. Pharmacol. 1986, 127, 139-142.

17. Lee, J.J.; Kim, Y.M.; Yin, S.Y.; Park, H.D.; Kang, M.H.; Hong, J.T.; Lee, M.K. Aggravation of LDOPA-induced neurotoxicity by tetrahydropapaveroline in PC12 cells. Biochem. Pharmacol. 2003, 66, 1787-1795.

18. Shin, J.S.; Yun-Choi, H.S.; Kim, E.I.; Lee, M.K. Inhibitory effects of higenamine on dopamine content in PC12 cells. Planta Med. 1999, 65, 452-455.

19. Shin, J.S.; Kim, E.I.; Kai, M.; Lee, M.K. Inhibition of dopamine biosynthesis by protoberberine alkaloids in PC12 cells. Neurochem. Res. 2000, 25, 363-368.

20. Shin, J.S.; Lee, J.J.; Kim, Y.; Lee, C.K.; Yun, Y.P.; Lee, M.K. Inhibitory effects of ethaverine, a homologue of papaverine, on dopamine content in PC12 cells. Biol. Pharm. Bull. 2001, 24, 103105.

21. Yin, S.Y.; Kim, Y.M.; Lee, J.J.; Jin, C.M.; Yang, Y.J.; Ma, J.J.; Kang, M.H.; Kai, M.; Lee, M.K. Enantio-selective inhibition of (1R,9S)- and (1S,9R)- $\beta$-hydrastines on dopamine biosynthesis in PC12 cells. Neuropharmacol. 2004, 47, 1045-1052.

22. Kim, Y.M.; Kim, M.N.; Lee, J.J.; Lee, M.K. Inhibition of dopamine biosynthesis by tetrahydropapaveroline. Neurosci. Lett. 2005, 386, 1-4. 
23. Lee, M.K.; Zhang, Y.H. Inhibition of tyrosine hydroxylase by berberine. Med. Sci. Res. 1996, 24, 561-562.

24. Lee, M.K.; Zhang, Y.H.; Shin, J.S.; Lee, S.S. Inhibition of tyrosine hydroxylase by hydrastine. Med. Sci. Res. 1997, 25, 619-620.

25. Zhang, Y.H.; Shin, J.S.; Lee, S.S.; Kim, S.H.; Lee, M.K. Inhibition of tyrosine hydroxylase by bulbocapnine. Planta Med. 1997, 63, 362-363.

26. Cho, S.; Neff, N.H.; Hadjiconstantinou, M. Regulation of tyrosine hydroxylase and aromatic Lamino acid decarboxylase by dopaminergic drugs. Eur. J. Pharmacol. 1997, 323, 149-157.

27. Yin, S.Y.; Lee, J.J.; Kim, Y.M.; Jin, C.M.; Yang, Y.J.; Kang, M.H.; Kai, M.; Lee, M.K. Effects of $(1 R, 9 S)$ - $\beta$-hydrastine on L-DOPA-induced cytotoxicity in PC12 cells. Eur. J. Pharmacol. 2004, 488, 71-77.

28. Bannach, R.; Valenzuela, A.; Cassels, B.K.; Nunez-Vergara, L.J.; Speisky, H. Cytoprotective and antioxidant effects of boldine on tert-butyl hydroperoxide-induced damage to isolated hepatocytes. Cell. Biol. Toxicol. 1996, 12, 89-100.

29. Youn, Y.C.; Kwon, O.S.; Han, E.S.; Song, J.H.; Shin, Y.K.; Lee, C.S. Protective effect of boldine on dopamine-induced membrane permeability transition in brain mitochondria and viability loss in PC12 cells. Biochem. Pharmacol. 2002, 63, 495-505.

30. Woo, S.H.; Sun, N.J.; Cassady, J.M.; Snapka, R.M. Topoisomerase II inhibition by aporphine alkaloids. Biochem. Pharmacol. 1999, 57, 1141-1145.

31. Kim, Y.K.; Ryu, S.Y. Cytotoxic components from stem bark of Magnolia ovobata. Planta Med. 1999, 65, 291-292.

32. Nagatsu, T.; Oka, K.; Kato, K. Highly sensitive assay for tyrosine hydroxylase activity by highperformance liquid chromatography. J. Chromatogr. 1979, 163, 247-252.

33. Lee, M.K.; Nohta, H.; Ohkura, Y. Occurrence of aromatic L-amino acid decarboxylase in human plasma and its assay by high-performance liquid chromatography with fluorescence detection. $J$. Chromatogr. 1986, 378, 329-336.

34. Chomczynski, P.; Sacchi, N. Single-step method of RNA isolation by acid guanidinium thiocyanate-phenol-cholroform extraction. Anal. Biochem. 1987, 162, 156-159.

35. Mosman, T. Rapid colorimetric assay for cellular growth and survival: application to proliferation and cytotoxic assays. J. Immunol. Meth. 1983, 65, 55-63.

36. Lowry, O.H.; Rosenbrough, N.L.; Farr, A.L.; Randall, R.L. Protein measurement with the Folin phenol reagent. J. Biol. Chem. 1951, 193, 265-275.

Sample availibility: Contact the authors.

(c) 2008 by MDPI (http://www.mdpi.org). Reproduction is permitted for noncommercial purposes. 